
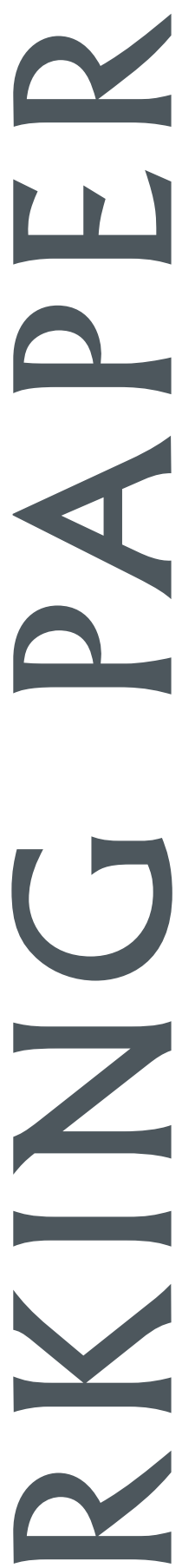

EAST-WEST CENTER 
The U.S. Congress established the East-West Center in 1960 to foster mutual understanding and cooperation among the governments and peoples of the Asia Pacific region including the United States. Funding for the Center comes from the U.S. government with additional support provided by private agencies, individuals, corporations, and Asian and Pacific governments.

East-West Center Working Papers are circulated for comment and to inform interested colleagues about work in progress at the Center.

For more information about the Center or to order publications, contact:

Publication Sales Office

East-West Center

1601 East-West Road

Honolulu, Hawaii 96848-1601

Telephone: 808-944-7145

Facsimile: 808-944-7376

Email: ewcbooks@EastWestCenter.org

Website: www.EastWestCenter.org 


\title{
The Reasons for and the Impact of Antidumping Protection: The Case of People's Republic of China
}

\author{
Tianshu Chu and Thomas J. Prusa
}

Dr. Chu is a Fellow in the Research Program at the EastWest Center, and an associated faculty in the Department of Economics at the University of Hawai'i at Manoa. Dr. Chu can be reached at ChuT@EastWestCenter.org.

Dr. Prusa is a Professor of Economics at Rutgers University, and a Faculty Research Fellow at National Bureau of Economic Research (NBER). He was a Visiting Fellow in the Research Program at the East-West Center in 2003. Professor Prusa can be reached at prusa@econ.rutgers.edu.

An earlier draft of this paper was presented at the APEC Capacity-Building Workshop on Quantification of NTMs and Trade Facilitation, October 8-10, 2003, in Bangkok, Thailand. The authors are very thankful for the financial support from APEC, and for the support from the organizing institutions, the Australian Productivity Commission and the U.S. International Trade Commission (USITC), and in particular Dr. Michael J. Ferrantino. The authors are also grateful for comments and suggestions from conference participants.

East-West Center Working Papers: Economics Series reports on research in progress. This paper has been peer-reviewed. The views expressed are those of the author and not necessarily those of the Center. Please direct orders and requests to the East-West Center's Publication Sales Office. The price for Working Papers is $\$ 3.00$ each plus shipping and handling. 


\section{The Reasons for and the Impact of Antidumping Protection: The Case of People's Republic of China}

\author{
Tianshu Chu \\ East-West Center
}

\author{
Thomas J. Prusa \\ Rutgers University and NBER
}

\section{Introduction}

Over the past few decades, the liberalization in international trade has progressed at rapid speed. Many traditional forms of barriers to trade, most importantly tariffs and quotas, have been reduced worldwide. Accompanying this great reduction in trade barriers has also been a great expansion in trade. Trade to GDP ratio has increased 86.1 percent from 1950 to 1990 , and a large proportion is likely to be accounted by the reduction in trade barriers. (Bergoeing and Kehoe 2003). While tariffs and quotas have been and continue to be reduced, another type of trade barrier, antidumping, is being used more and more frequently as a measure of protection. (Prusa and Skeath, 2002). Further complicating the role of antidumping is the fact that the economies who are being affected by antidumping protection has changed over time; traditionally antidumping was used by and against developed economies, but over the past decade developing economies have emerged as frequent targets (and users) of antidumping (Prusa, 2001; Fu, 1997).

In this paper, we focus on the case of China, to explore the characteristics, the reasons for and implications of antidumping. China initiated trade liberalization about 25 years ago, and since has observed an accelerated increase in exports. Coincidental with its increased exports, China has also become the largest targeting economy of antidumping (AD) trade disputes. There are many aspects of AD that explain why China is more susceptible to 
antidumping, including its non-market economy (NME) status. Yet, as suggested by Blonigen (2003), even after controlling for all these unfavorable factors, China is subject to an inexplicably large number of antidumping attacks.

The literature on antidumping against China includes several articles that review the use of AD by EU (Vermulst and Graafsma, 1992; Liu and Vandenbussche, 2002; Mai, 2002; Eeckhout, 1997; Wang, 1999), and two that examine the US AD cases (McGee, 1999; Kao, 1990). A recent working paper by Messerlin (2002) also discusses the characteristics of $\mathrm{AD}$ activity against China.

Our paper builds on the previous studies, and make new contributions in analyzing the reasons for China being so broadly and intensively targeted. In particular, the domestic characteristics of exports structure and industrial structures are examined. Our analysis also reveals that foreign direct investment (FDI) may be a significant factor explaining $\mathrm{AD}$ cases against China. There is also evidence that low concentration ratios in Chinese industries have contributed to the competitive price and low profit margins.

The next section discusses the characteristics of AD cases targeting Chinese imports. We then analyze the reasons for $\mathrm{AD}$ activity against China and discuss some implications for the Chinese economy. We make a few concluding comments in the final section. 


\section{Characteristics of AD Cases Against China}

We would like to establish a set of stylized facts about AD targeting China, focusing on the size, trend, intensity, and broadness.

\section{A. The size and the trend}

As it is well known, China is the largest target economy for AD cases. The total number of AD cases targeting China reached 457 by the end of 2001, making China's total only slightly lower that all of the EU economies combined. If current trends continue, China will surpass the EU in the near future. China is easily the largest target when compared with any individual economy.

In Table 1, we present the time series since 1980 of the top six economies affected by AD investigations. The US was the top target economy during the early 1980s; it was then replaced by Japan who remained the most targeted economy during the rest of the 1980s. Since 1992, China has been the top targeted economy every year. Not only is it the largest affected economy, but also the number of cases against China easily surpasses the level of the US and Japan when they were the leading targets. Overall even though China only become a significant target in the past ten years, its total number of $\mathrm{AD}$ cases has surpassed the US and Japan, and China has emerged as the largest targeted economy.

Not only is the number of AD cases targeting China high, but also the trend is positive and increasing at a rapid rate. The number of cases against China was relatively small in 
the early to mid 1980s; since 1988, however, there has been a marked increase in the number of cases against China by both the EU and the US (Vermulst and Graafsma, 1992).

In order to quantify this trend in AD filings we have applied a simple fixed effect OLS model:

$$
n_{i t}=a_{i}+b \times t+b_{i} \times t
$$

where

$$
\begin{aligned}
& n_{i t}=\text { number of cases filed against economy } i \text { at time } t \text { (e.g., each year) } \\
& a_{i}=\text { economy fixed effect } \\
& b_{i}=\text { economy-specific trend } \\
& t=\text { time trend }
\end{aligned}
$$

In table 2 we report our estimates. Note that our regression includes an time dummy for each economy; however, for space reasons we only report the parameters for the nine economies with statistically significant estimates. As shown it turns out, the time trend for most economies is insignificant; in addition, most economies with significant estimates have negative trends. There are only four economies showing positive trends: China, Indonesia, Korea and Thailand. The time trend for China is the steepest of all target economies. As can be seen in Figure 1, the other three economies with a positive coefficient have much milder slope in comparison with China. Moreover, as we will discuss later (Table 6) it is developing economies such as India and Mexico that are main contributors to the steep upward trend. Therefore, in the foreseeable future, China is 
likely to stay as the most named economy in $\mathrm{AD}$ filings and is going to see continuing increase in the share of total AD filings.

\section{B. The intensity}

Because of China's growing international trade and growing size of the economy, it is perhaps not surprising to see it being named frequently in AD filings. After all, more trade may simply lead to more filings against it. The next question to ask, then, is whether China is also being named more intensively than other economies given its trade value. The answer is positive.

The intensity of $\mathrm{AD}$ against China is high. As we have already shown China is the leading $\mathrm{AD}$ target. In terms of international trade, China ranks as the sixth largest in the world both in terms of exports and imports. This disparity suggests the intensity of AD use against China is high. To quantify this point we compute three indicators for intensity of being targeted for $\mathrm{AD}$ (see Table 3). The first is the "AD-export" ratio, which is defined as an economy's share of AD cases in the world divided by its share in world exports. If an economy's AD-export ratio is above 1 , it means that the economy is being targeted more than its share in exports.

Consider China's intensity number. China accounts for about 4.3 percent of total world exports in 2001, and an astounding 17 percent of all AD cases (1995-2002). Therefore, according to this measure China receives four times as much as $\mathrm{AD}$ investigations as one 
might predict given its share in world exports $(\mathrm{AD}$-export ratio $=4)$. Korea, Indonesia, India and South Africa are also among the other high AD-export ratio economies.

A second indicator is an economy's affirmative ratio, which is defined as the number of measures (i.e., duties levied) divided by the number of initiations targeting a particular economy. During the period of 1995-2002, 69 percent of all AD initiations against China received an affirmative final determination. While this number is high, there are several other economies that have even higher ratios, such as Japan, Russia, Brazil, Ukraine, and Singapore.

Our third intensity measure combines the first two in order to indicate the overall possibility of an economy's exports being subject to AD duties. This third measure is reported in the final column where we calculate the product of the first two measures. With this third measure, China ranks $3^{\text {rd }}$, trailing Ukraine and India. However, one needs to remember that the total number of cases against India and Ukraine combined is only 40 percent of the total against China. In this sense, China exports bear the most significant brunt of AD protection.

One important caveat: one must recognize that all of the above three measures offer only crude estimates of AD intensity. There are a number of weaknesses in these measures, not the least is that none of them accurately measure the amount of trade being affected in any given case. 


\section{The AD measures}

The duties resulting from the final determination can be very high in AD cases against China. In many cases, the measures are prohibitive. For instance, Liu and Vandenbussche (2002) and Fu (1997) examine EU AD against China. The two studies look at different time periods but both find that the AD duties imposed by the EU are high. Liu and Vandenbussche (2002) report the average antidumping duty (ADD) is around 41 percent, ranging from 10 to 102 percent. Fu (1997) examines the trade impact of the duties and finds dramatic decreases in trade. For instance, after the EU imposed AD measures on Chinese exports of Tungstic Oxide and Tungstic Acid, and Barium Chloride in 1988, the exports of these products from China to the EU dropped by 96 percent in four years. Similarly, exports of small color televisions, polyester yarns and videotapes in cassettes dropped over 90 percent.

We have compiled antidumping duty (ADD) data for the US against Chinese exports; our result indicates even higher ADD than observed by the EU against Chinese exports. Among the 60 AD cases for which we have information on ADD, 11 had ADD above 100 percent, and 6 of them the ADD is above 150 percent; 17 cases had ADD duties between 50 and 100 percent. Altogether, nearly half of US cases against China had ADD above 50 percent. The average ADD is 54 percent

The AD duties from the developing economies (what are often referred to as the new users) tend to be even higher than those applied by the EU and US. For example, Brazil 
currently has ADD imposed on 12 types of Chinese products, with margins ranging from 35.8 percent to 203.4 percent, with an average around 77 percent.

\section{The sectors being named}

We also investigate the type of Chinese products that are targeted by AD investigations. Our results indicate that the range of industries that have been the targets for $\mathrm{AD}$ is amazingly wide. In terms of two-digit ISIC classification of industries, all 2-digit manufacturing industries have been targeted (Table 4). In terms of three-digit ISIC classification, 26 out of total 29 (3-digit) ISIC manufacturing industries. Such widespread coverage not only demonstrates China's diverse economy and widespread comparative advantage, but it also demonstrates how comprehensive and versatile tool antidumping can be, allowing an economy to protect virtually any filing industry, regardless whether the industry has comparative advantage.

Despite the breadth of Chinese industries being targeted, the frequencies for some industries are particularly high. Four sectors account for 80 percent of all AD filings: "Manufacture of Chemicals and Chemical, Petroleum, Coal, Rubber and Plastic Products", “ Manufacture of Fabricated Metal Products, Machinery and Equipment", "Textile, Wearing Apparel and Leather Industries", and "Basic Metal Industries". The first two sectors account for 55 percent of all AD filings. The filing trends suggest that the simple basic manufacturing industries which China has its greatest cost advantages are also the ones being hit the hardest by AD. 
The most frequently targeted industries at the four-digit classification level are "Manufacture of basic industrial chemicals except fertilizers" and "Iron and steel basic industries", which together account for 25 percent of all filings. Activity against the other 4-digit sectors are fairly evenly spread out, with 19 sectors having been subject to 9 to 23 cases, and 37 sectors named from once to six times (Table 5).

\section{E. The filing economies}

The next issue we examine is the question of who is targeting Chinese exports. We find that China has been targeted by a wide array of economies. Treating all EU members as one economy, there have been 25 economies that have launched $\mathrm{AD}$ investigation against Chinese exports.

Among the top initiators are: US, EU, India, Australia, Argentina, and Mexico; together they account for 72 percent of all $\mathrm{AD}$ cases filing against China. $\mathrm{AD}$ activity, therefore, is concentrated among a handful of major users. In order to examine whether there are significant differences in the filing intensity we computed each economy's filing intensity and relative filing intensity as:

$$
\begin{array}{cl}
\text { Intensity }_{i} & =\text { Number of filings against China }_{i} / \text { Imports from China }_{i} \\
\text { Relative Intensity }_{i} & =\text { Intensity }_{i} / \text { Intensity }_{U S}
\end{array}
$$

As shown in Table 6, South Korea, the US and EU are among the least intensive economies using AD to target Chinese exports. Developed economies with high 
intensities are Australia and New Zealand, which are 8.4 and 11.5 times more likely to file an $\mathrm{AD}$ case relative to the US. The truly large users are developing economies such as Argentina (relative intensity=46.8), Peru (42.4), India (18.1) and Mexico (15). Not surprisingly, these economies all compete in labor-intensive industries that are most likely losing (or have lost) comparative advantage in those industries to China.

In summary, with respect to $\mathrm{AD}$ investigations targeting China we have shown that:

1. China constitutes the largest single economy being targeted by AD investigations;

2. The trend in using $\mathrm{AD}$ against China is positive and is growing faster than any other economy;

3. The intensity which Chinese exports are targeted is high; the likelihood that ADD are imposed is high;

4. When they are imposed, AD duties are very high, often prohibitive;

5. The sectors covered is broad, nearly comprehensive;

6. A large number of developing and developed economies target Chinese exports; filing intensities varies widely across filings economies.

While in some respects China is not unique as many developing economies have broadly similar stories of AD abuse, especially in terms of the high intensity and high likelihood of duties being levied. Taking all factors together, however, China clearly emerges as the economy most severely affected by AD. 


\section{The Reasons for High China's AD Intensity and High AD Duties}

In this section, we investigate the reasons for the large number and high intensity of $\mathrm{AD}$ investigations targeting China, as well as the high $\mathrm{AD}$ duties in $\mathrm{AD}$ cases against China.

First we document the likely contributing factors that are shared with other economies, such as the strategic use of AD, NME status, the role of cumulation, and inexperienced and ineffective legal defenses. We then focus on a couple of factors that are very unique in China, the roles played foreign direct investment (FDI) through foreign invested enterprises (FEI) and the low concentration ratio in many Chinese industries.

\section{A. AD as a learned strategy for domestic firms blocking foreign competition}

To what extent is $\mathrm{AD}$ a learned strategic behavior? How can we account the proliferation of AD across industries and across economies? Prusa and Skeath (2002) and Fu (1997) argue that it is likely that firms learn that $\mathrm{AD}$ can be used strategically to block foreign competition. In the case of China, because of its rapid increase in trade, the publicity about China is abundant. Publicity about China lowers the cost of acquiring information needed in the AD petition. We have examined the possibility of copying from the same industries across economies in launching $\mathrm{AD}$ investigations as an indication of an informational spillover. A simple measure is to check how many antidumping cases for the similar products occur within one year of one other in different economies (e.g., similar case against Chinese exports by both EU and US within one year). If a case is 
launched shortly after a similar case by another economy, we will say the second "echoes" the initial filing.

We find that there have been 83 cases against China that could be said to echo. That is, these cases were initiated within one year of another economy initiating an AD case involving the same or very similar products. Cases involving textiles and footwear frequently echoed. For example, in the case of textiles, EU, Mexico, Turkey and Peru each launched $\mathrm{AD}$ investigations on a wide array of textile products within a short time frame.

We believe our measure is conservative in two senses. First, we restrict our measure to only one year, however, a span of 18 month or longer could be reasonably called an echoing period. Moreover, the learning could occur across wide array of products (echoing within an economy rather than between economies). For example, Mexico had AD investigations covering HS codes 52, 53, 54 and 55, and Peru had investigations covering "various fabrics". Simply put, it seems likely that the learning occur across industries, which is a type of learning that our measure does not capture.

Can AD initiation be a learned tactic for declining industries? This seems to be a very logical tactic for some industries. It is fairly commonly observed that $\mathrm{AD}$ investigations involved the same (or similar) line of products are filed repeatedly over time. Steel is perhaps the best example where both the US and EU have filed AD investigations involving many types of Chinese steel over the past decade. Australia launched 
investigation on canned pear and peaches, and soon thereafter started investigation on canned tomatoes. In $\mathrm{EU}$, the $\mathrm{AD}$ investigation against Chinese made cotton fabrics was initiated three times in 1994, 1996 and 1997.

Therefore, it seems that $\mathrm{AD}$ protection can be contagious across economies and becomes a learned behavior over time. If an $\mathrm{AD}$ action against foreign competitor can achieve an affirmative result with a high probability, or if it deters the imports through litigation costs, then $\mathrm{AD}$ is more likely to become a learned behavior. Unfortunately, this seems to be the case. According to various studies (Prusa and Skeath 2002, Fu 1997), AD investigations have successfully deterred imports and raised profitability of initiating firms, therefore, the economic rational for troubled firms to initiate AD is very strong.

\section{B. Non-market economy (NME) status}

There are a few widely recognized reasons that Chinese exports receive disproportional amount of $\mathrm{AD}$ investigations. China's non-market economy status is arguably the most commonly cited explanation.

The GATT/WTO antidumping rules allow an investigating economy to not use the exporter's domestic prices when calculating the home market sales, input costs, etc. Being classified as a non-market makes it extremely difficult (virtually impossible) for exporting economy to defend itself. China has always been classified as a non-market 
economy. In the accession protocol to WTO, China agreed that this non-market treatment would not be phased out for another 15 years (will expire in 2016).

The argument is that China is not considered a market economy; thus Chinese domestic prices do not reflect the true cost of these inputs as determined in the markets. Therefore, during the investigation of antidumping case targeting China, the investigators do not have to use the Chinese domestic input prices in determining the cost of the production of the investigated product.

This practice renders greatly increases China's risk in dumping allegations because the low cost of labor services is its major comparative advantage for international trade. In practice, China's non-market economy status hands greater discretionary power to the investigators, who have the option to choose an economy with high prices when evaluating the cost of inputs in China. For example, in a recent investigation in brake rotors by the US, the handling and freight cost was calculated using India cost. India is known for higher cost of transportation than most of its neighbors. ${ }^{1}$ Therefore, using India price would increase the likelihood of affirmative result.

Even though non-market status contributed to unfavorable determination in $\mathrm{AD}$ investigations against China, it is probably not sufficient to explain the large number of cases targeting China (Blonigen, 2003). Even after controlling for China's non-market

\footnotetext{
${ }^{1}$ [Federal Register: January 8, 2003 (Volume 68, Number 5)][Page 1031-1038] [DOCID:fr08ja03-24] [A570-846] Brake Rotors from the People's Republic of China: Preliminary, Results and Preliminary Partial Rescission of the Fifth Antidumping, Duty Administrative Review and Preliminary Results of the Seventh New Shipper Review.
} 
status, Blonigen still finds a significantly positive unexplained "China factor". Therefore, there are other factors that are not yet well captured or measured by economists that contribute significantly to China's being the largest targeted economy.

\section{Cumulation}

Cumulation is another factor that increases the number of cases against China. As is well known, China has experienced a rapid expansion of the international trade. Its share of world trade has increased seven-fold and China's volume of international trade increased 40-fold during 1977-2001. ${ }^{2}$ With the rapid growth of international trade, it is inevitable that the China's import market share in a particular economy will rise rapidly from nonexistent or very small to above the low threshold for cumulation. Therefore, even though Chinese imports in many products still capture only a small proportion of the market, with the cumulative assessment of the market share, China is included in the investigation even though China is not (at the time of the filing of the case) a significant exporter to foreign markets. Hansen and Prusa (1996) document that the mandatory cumulation in 1984 in the US has led to significant increase in the possibility of finding injuries. Since most AD initiations against China have occurred since the late 1980s, therefore, cumulation has likely contributed to the large number of cases filed against China as well as the intensity against China.

\section{Weakness in corporate governance prevents effective defense in AD investigations}

\footnotetext{
${ }^{2}$ The data source is World Development Indicator 2003.
} 
It has been noted that, especially in the first decade of facing $\mathrm{AD}$ investigations, Chinese enterprises have not coordinated well or presented their case in an effective manner. This reflects the overall weakness of Chinese enterprises in terms of the backward corporate governance practice, and also the overall weakness of the nationwide legal infrastructure.

Chinese enterprises often do not respond in a timely manner, and cannot afford high cost for hiring lawyers of experiences, and in some cases just not responded at all. China has a tradition of having a weak legal system, and Chinese traditional values do not encourage litigation. The SOE status is much to account for this behavior, where the managers have little incentive to fight for the SOE's behalf where they personally have little stake. Moreover, even when some are willing to cooperate, they lack the authority as well as the necessary skill and information to respond effectively.

On top of this, the macro coordination effort still needs improvement. One piece of evidence is that among all 53 cases of the WTO dispute involving antidumping issues, none has been filed by China. ${ }^{3}$ In fact, China is the only one economy among the top-ten target economies that has not filed a single WTO dispute on AD issues.

China was not eligible to file complaints to the WTO Dispute Settlement Body (DSB) before it became a member in 2002. Yet, of the approximately 200 AD cases targeting

\footnotetext{
${ }^{3}$ See http://www.wto.org/english/tratop_e/dispu_e/dispu_subjects_index_e.htm\#bkmk4 for list of AD disputes.
} 
China annually, it is unlikely that all cases are handled in conformity with WTO laws. It is still unclear if China will begin to lodge some complains to DSB in the near future.

It remains to see whether filing complaints has any impact on the cases initiated or not. If it does, as common sense would predict, then the fact that China does not use the DSB might lead the initiating economy over-reach in its efforts to levy ADD on cases against China. This issue is not a factor controlled in Blonigen's (2003) study that found a significant positive "China effect" in AD activity. Future research should examine whether WTO DSB has any deterrent effect on AD activity.

\section{E. Foreign direct investment and the "antidumping (AD) triangle"}

Once China relaxed the regulations governing FDI in 1992 inward FDI has increased dramatically. Currently the foreign invested enterprises (FIE), the firms with FDI, account for roughly 50 percent of both Chinese imports and exports.

Blonigen (2000) documented that FDI is one means for a foreign firm to avoid a tariff or $\mathrm{AD}$ duty or what he refers to as tariff-jumping. We explore the related hypothesis that FDI might play an important role in explaining the large number of $\mathrm{AD}$ filings against Chinese exports. A significant amount of Chinese FDI has been from the four East-Asian Tigers and has resulted in Chinese-sourced exports have replaced exports from parent company home markets. It is natural to hypothesize that $\mathrm{AD}$ filings against China are 
also replacing $\mathrm{AD}$ filings against these economies. This is a particular type of tariff jumping by multinationals not previously discussed in the literature.

Due to data limitation, at this time we cannot fully explore the "AD triangle" hypothesis. What we can do, however, is document the correlation of FDI flow into China with the number $\mathrm{AD}$ filings against China. Our result shows that the number of $\mathrm{AD}$ filings against Chinese exports is increasing significantly in FDI. The estimating equation is:

$$
n_{t}=a+b_{1} \ln \left(F D I_{t}\right)+b_{2} \ln \left(\text { Exports }_{t}\right)+b_{3}\left(\text { Exchange rate }_{t}\right)+e_{t},
$$

where

$$
\begin{aligned}
& n_{t}=\text { number of cases filed against China at time t (e.g., each year) } \\
& \mathrm{FDI}_{t}=\text { inward flow FDI at time } t \\
& \text { Exports }_{t}=\text { Chinese exports at time } t \\
& \text { Exchange Rate }_{t}=\text { exchange rate (Yuan per dollar) at time } t
\end{aligned}
$$

Because the dependent variable is a count variable, we use Poisson regression model. As can be seen in Table 8, FDI is the only significant explanatory variable, and it is significant at the 99 percent level. Exports are statistically insignificant and the exchange rate has wrong sign. ${ }^{4}$ As shown in Figure 3, the high correlation between FDI and AD filings is obvious. This simple regression lends strong support for the notion that Chinese

\footnotetext{
${ }^{4}$ When we test each explanatory variables individually, they are all-significant and have correct signs, but the FDI has the highest pseudo r-square value.
} 
FDI inflow plays an important role in the number of AD cases filed. This is also consistent with the proposed special type of tariff jumping, the "AD triangle".

\section{F. Low concentration ratio in Chinese industries}

One particular feature of Chinese industries is their very low concentration ratios. Existing studies focus on the geographic concentration, which is high (Amiti and Wen 2002). However the market concentration is very low. Even though no much literature has been found on this, low concentration is a well-recognized fact, and in the Tenth Five-year Plan on Industrial Structure Adjustment, the fact that production concentration is low was recognized as one of the major problems of current industrial structure in China. According to the analysis in the Third Industrial Census (National Statistic Bureau 2003), one of the major problem is "small and scattered scale of industrial organization".

A brief comparison can demonstrate the huge difference in concentration level in industries between China and the US. In the US, 50 largest industrial firms count for $23 \%$ of total production in manufacturing (in year 1997), and top 201 firms count for $60 \%$ of total $^{5}$. Whereas in china, 375 largest firms produce $16 \%$ of total industrial output in 2001 , and it takes an enormous number of 22,987 firms to produce $60 \%$ of total industrial output $^{6}$. The difference is huge. Even though the US data is for manufacturing only and China data is for all industries including manufacturing, utility and mining sectors, it does not affect the result much. In the US, mining counts only $4 \%$ and utility counts for $9 \%$ of

\footnotetext{
${ }^{5}$ Data source: 1997 Economic Census, US Census Bureau.

${ }^{6}$ Data source: Table 13-1, China Statistical Yearbook, 2003.
} 
industrial output, thus it can only affect slightly the overall US concentration level presented above ${ }^{7}$. Therefore, the statistics strongly indicates that Chinese industries are far less concentrated than that of the US.

Given very low production and market concentration, profitability of Chinese firms is reduced. The low profit margins, when facing $\mathrm{AD}$ investigation, which typically specify high profit margin when evaluating cost of production, can lead to higher imposed duties. This is still only a hypothesis and need further investigation whether its impact is significant enough leading to quantitative impacts on $\mathrm{AD}$ determinations. The low profit margin in Chinese firms can also lead to undercutting the exports prices, which will lead to more $\mathrm{AD}$ initiations.

The mirror problem of the low concentration and low profit margin in Chinese industries is the relatively high concentration ratio and higher profitability in many major $\mathrm{AD}$ initiating economies. In the highly concentrated industries, the firms exhibit more strategic behavior, and are more likely to utilize the tool of $\mathrm{AD}$ regulation to block the foreign competition. This has been confirmed by the study on EU AD (Liu and Vandenbussche, 2002) who document that the majority of AD files are filed by highly concentrated industries; in many cases monopolists and oligopolies in the EU market; a very small proportion (less than 15 percent) involve not so concentrated industries. This statistic also applies to the US, another major user of $\mathrm{AD}$, where the industrial

\footnotetext{
${ }^{7}$ In fact, the utility sector in the US is also very concentrated, with 4 largest firms counting $15 \%$ of total revenue of the sector. The mining sector is less concentrated, but with its $4 \%$ share of total output, it will produce only negligible impact on overall concentration level. Data source: 1997 Economic Census, US Census Bureau.
} 
concentration among industries using AD is high (Hansen and Prusa, 1996). In many respects, this finding illustrates one of the great ironies of $\mathrm{AD}$ regulation --- instead of creating "fair" competition, it punishes the competitive international industries, and encourage uncompetitive domestic behavior.

\section{Implications}

It is a difficult task to evaluate the impacts of AD on China. One reason is the lack of data, but another is that the dynamic impacts are yet to be fully understood. For instance, the US uses individual treatment, which often gives one (or a few Chinese exporters) smaller ADD and all other Chinese exporters, current or future, a very high ADD. In this case it not only alters the trade pattern, it also will affect the industrial structure in China. However, these effects are hard to use a formal treatment to estimate, therefore in this section we only discuss qualitatively some likely impacts of the large, growing, intensive, severe, and broad $\mathrm{AD}$ filings against Chinese exports.

The amount of Chinese exports affected by $\mathrm{AD}$, among trade remedies, is the second largest, only trailing technical barriers. According to Yue (2003), the cumulated amount of exports that have been affected has reached 16 billion US dollars. Fu (1997) estimates that about 5 percent of Chinese exports to EU are affected by EU AD filings. This number is very large considering the strong deterring effect of $\mathrm{AD}$ investigation on imports. In comparison with tariffs, ADD are very high and target the particular products. 
As we have discussed in the intensity of AD from various economies, EU is modest in terms of intensity of filing, therefore, it is very likely in other economies, the trade affected will be much higher than 5 percent of total. Therefore, the amount of trade affected is very significant. The cost is also to employment, which will be adversely affected through the decrease in exports, which will further complicate China's continuing economic transition.

Moreover, learning from the lessons of antidumping, some Chinese manufactures have begun to form alliance, restricting the price of exports to the US. For example, the apple cider producers in China now meet annually to determine the minimum price to the US. It is natural to see more and more firms become aware and begin to charge higher export prices toward major users of AD. This might contribute toward increasing the concentration ratio in Chinese industries, or even create monopolies or oligopolies in exports markets.

Moreover, according to our finding on the role of FDI in explaining the AD filings, the multinationals or foreign investors are likely hurt by AD filings against Chinese exports.

Will China become a new important user of AD? We think yes. The number of cases filed by China is increasing rapidly. We have illustrated in Figure 4 the number of cases initiated by China, which has a clear positive trend. There is no evidence China has used $\mathrm{AD}$ as a retaliation toward economies filing $\mathrm{AD}$ against Chinese exports, however, it should be recognized that China has it own industries to protect, and it might find that 
$\mathrm{AD}$ can be a very convenient instrument for protection. The ongoing pressure of unemployment, and the fact that much needed expansion of Chinese exports sector employment is constrained by the foreign AD filings, it is natural for China to use the same tool to retain employment. If this occurs, $\mathrm{AD}$ will lead to mutual welfare worsening effects.

\section{Conclusion}

We have examined the case of $\mathrm{AD}$ filings for Chinese exports, the largest in the world, in this paper, and document the characteristics of these AD filings. We have shown that $\mathrm{AD}$ activity against China has involved and continues to involve a large number of filings; that $\mathrm{AD}$ use against China is increasing; that intensity of $\mathrm{AD}$ use against China is high; that Chinese cases often involve very high duty levels; that $\mathrm{AD}$ cases against China have broad industrial coverage, and have been initiated by many economies. We then analyze the possible causes and/or contributing factors for the use of $\mathrm{AD}$ against China. Besides common factors being recognized by other studies, such as non-market economy status and cumulation, we have found two important and unique contributing factors in China, the FDI inflow and the low concentration ratio in Chinese industries.

The FDI hypothesis is related with studies on tariff jumping, yet it is different that it involves not investing in the $\mathrm{AD}$ initiating economy, which might not have comparative advantage. Some of the FDI inflow to China might be from foreign firms that were subjected to anti-dumping, either in its home economy or a third economy that it had 
foreign investment, to relocate to China, which has not been subjected to AD filings yet and which has comparative advantages in these industries. We are not able to directly test this hypothesis, however, our result is consistent with it. It requires multi-economy study to further explore the validity of this hypothesis.

Our review of AD filings against China has confirmed that the $\mathrm{AD}$ practice can be very convenient and effective tool to deter trade and that it has a number of dynamic impacts that are hard to quantify. China is likely to follow other new users of $\mathrm{AD}$ if the filings against Chinese products continue to rise and obstruct the creation of employment in export sector to absorb unemployment from the dismantled industries as a result of WTO transition and other reforms. Should this happen, significant welfare cost will occur to both China and its trade partners.

\section{References}

Almstedt, Kermit W; Norton, Patrick M, 2000. "China's Antidumping Laws and the WTO Antidumping Agreement: (Including Comments on China's Early Enforcement of Its Antidumping Laws.)", Journal of World Trade, vol. 34, no. 6, December 2000, pp. 75113

Amiti, M. and M. Wen, 2002. "Spatial distributon of manufacturing in China", in Modeling the Chinese Economy, ed. By P. loyd and X. Zhang, London; Edward Elgar.

Bergoeing, R. and Kehoe, T. 2003. "Trade Theory and Trade Facts", Federal Reserve bank of Minneapolis, Research Department Staff Report 284, October 2003.

Blonigen , Bruce, 2003. "Evolving Discretionary Practices of U.S Antidumping Activity", NBER Working Paper No. w9625, April 2003

Blonigen, Bruce, 2000. “Tariff-Jumping Antidumping Duties”, NBER Working Paper No. w7776, July 2000 
Blonigen, Bruce and Thomas J. Prusa, "Antidumping" in Handbook of International Economics, E. Kwan Choi and James Harrigan, eds. (Malden, MA, Blackwell

Publishing), 2003.

China's Modernization and Open Economic Policy, edited by M. Dutta, Pei-Kang Chang, and Shao-Kung Lin. JAI Press, 1990, p. 333-36.

Chinese National Bureau of Statistics, 2003. "The current status, problems and solution of industrial structural adjustment", Analysis number 23 on Third Industrial Census. (Chinese)

Dong, Yi; Xu, Huijun; Liu, Fang, 1998. "Antidumping and the WTO: Implications for China”, Journal of World Trade, vol. 32, no. 1, February 1998, pp. 19-27

Eeckhout, Piet, 1997. "European Antidumping Law and China”, European Integration online papers, vol.1, $\mathrm{n}^{\circ}$ 7. http://eiop.or.at/eiop/texte/1997-007.htm

Fu, Donghui, 1997. "EC Antidumping Law and Individual Treatment Policy in Cases Involving Imports from China”, Journal of World Trade, vol. 31, no. 1, February 1997, pp. $73-105$

Gupta, P and A. Panagariya, 2003. Injury Investigations in Antidumping and the SuperAdditivity Effect: A Theoretical Explanation, University of Maryland working paper.

Hansen, Wendy L. and Thomas J. Prusa, "Cumulation and ITC decision-making: The sum of the parts is greater than the whole," Economic Inquiry, 34, 1996, 746-769.

Huang, Thomas Weishing, 2002. "The Gathering Storm of Antidumping Enforcement in China”, Journal of World Trade, vol. 36, no. 2, April 2002, pp. 255-83

Kao, Hung-Yeh, 1990. "The Theory of Comparative Advantage: American Antidumping Procedure against Chinese Goods China's modernization and open economic policy. 1990, pp. 333-36, Research in Asian Economic Studies, vol. 2. (Greenwich, Conn. and London: JAI Press).

Liu, Xiang; Vandenbussche, Hylke 2002. "European Union Antidumping Cases against China: An Overview and Future Prospects with Respect to China's World Trade Organization Membership", Journal of World Trade, vol. 36, no. 6, December 2002, pp. $1125-44$

Mai, Y. H. 2002. “An Analysis of EU Antidumping Cases against China”, Asia-Pacific Development Journal, vol. 9, no. 2, December 2002, pp. 131-50

McGee, Robert W, 1999. "Antidumping Laws, the World Trade Organization and the People's Republic of China: The managerial process and impact of foreign investment in 
Greater China", Advances in Chinese Industrial Studies, vol. 6. pp. 141-55, (Stamford, Conn.: JAI Press).

Messerlin, Patrick A., China in the WTO: Antidumping and Safeguards, December, 2002, mimeo.

Prusa, Thomas J. and Susan Skeath, "The Economic and Strategic Motives for Antidumping Filings," Weltwirtschaftliches Archiv, 138(3), 2002, 389-413.

Prusa, Thomas J., "On the Spread and Impact of Antidumping," Canadian Journal of Economics 34(3), August 2001, 591-611.

Prusa, Thomas J., "The trade effects of U.S. antidumping actions," in Effects of U.S.

Trade Protection and Promotion Policies, Robert C. Feenstra ed., (University of Chicago Press, Chicago, 1997).

Stahnke, Arthur A, 1981. "The West German System of Protection against Dumping by Centrally Planned Economies”, ACES Bulletin, vol. 23, no. 1, Spr. 1981, pp. 1-24

Tharakan, P.K.M., D. Greenaway and J. Tharakan, 1998, "Cumulation and Injury Determination of the European Community in Antidumping Cases", Weltwirtschaftliches Archiv, 134, 2, 320-339.

Vermulst, Edwin A; Graafsma, Folkert, 1992. "A Decade of European Community Antidumping Law and Practice Applicable to Imports from China”, Journal of World Trade, vol. 26, no. 3, June 1992, pp. 5-60

Wang, Jianyu, 1999. "A Critique of the Application to China of the Non-market Economy Rules of Antidumping Legislation and Practice of the European Union", Journal of World Trade, vol. 33, no. 3, June 1999, pp. 117-45.

Wang, Lei; Yu, Shengxing, 2002. "China's New Antidumping Regulations: Improvements to Comply with the World Trade Organization Rules", Journal of World Trade, vol. 36, no. 5, October 2002, pp. 903-20

Yue, Hao, 2003. "A Study on the Unfairness of the International Antidumping," International Economic Cooperation, February, 2003. ISSN1002-1515 CN11-1583/F 
Table 1. Top Six Antidumping Targets, 1980-2001

\begin{tabular}{|c|c|c|c|c|c|c|c|c|}
\hline & $\begin{array}{l}\text { CHINA } \\
\text { (PRC) }\end{array}$ & USA & $\begin{array}{l}\text { SOUTH } \\
\text { KOREA }\end{array}$ & JAPAN & $\begin{array}{c}\text { USSR } \\
\text { (FORMER) }\end{array}$ & $\begin{array}{c}\text { CHINESE } \\
\text { TAIPEI }\end{array}$ & OTHER & TOTAL \\
\hline 1980 & 1 & 20 & 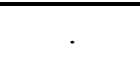 & 5 & . & 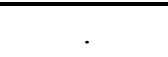 & 43 & 69 \\
\hline 1981 & 1 & 11 & 5 & 9 & 1 & 4 & 62 & 93 \\
\hline 1982 & 8 & 20 & 17 & 19 & . & 5 & 148 & 217 \\
\hline 1983 & 8 & 16 & 12 & 21 & . & 10 & 106 & 173 \\
\hline 1984 & 6 & 13 & 9 & 19 & 2 & 7 & 95 & 151 \\
\hline 1985 & 8 & 14 & 12 & 20 & 1 & 12 & 135 & 202 \\
\hline 1986 & 6 & 14 & 11 & 18 & . & 11 & 100 & 160 \\
\hline 1987 & 1 & 18 & 8 & 19 & 1 & 6 & 66 & 119 \\
\hline 1988 & 5 & 10 & 12 & 18 & . & 8 & 69 & 122 \\
\hline 1989 & 4 & 8 & 6 & 10 & 1 & 6 & 61 & 96 \\
\hline 1990 & 12 & 18 & 11 & 13 & 3 & 11 & 97 & 165 \\
\hline 1991 & 16 & 16 & 12 & 18 & 16 & 10 & 140 & 228 \\
\hline 1992 & 31 & 26 & 25 & 14 & 19 & 15 & 190 & 320 \\
\hline 1993 & 45 & 31 & 17 & 11 & 21 & 11 & 161 & 297 \\
\hline 1994 & 44 & 14 & 8 & 7 & 37 & 5 & 119 & 234 \\
\hline 1995 & 20 & 12 & 14 & 5 & 9 & 4 & 92 & 156 \\
\hline 1996 & 43 & 21 & 11 & 6 & 11 & 9 & 123 & 224 \\
\hline 1997 & 33 & 15 & 15 & 12 & 17 & 16 & 135 & 243 \\
\hline 1998 & 28 & 15 & 24 & 13 & 21 & 10 & 136 & 247 \\
\hline 1999 & 41 & 14 & 34 & 22 & 29 & 22 & 187 & 349 \\
\hline 2000 & 43 & 13 & 22 & 9 & 18 & 16 & 157 & 278 \\
\hline 2001 & 53 & 13 & 19 & 12 & 13 & 19 & 211 & 340 \\
\hline TOTAL & 457 & 352 & 304 & 300 & 220 & 217 & 2633 & 4483 \\
\hline
\end{tabular}


Table 2. Filing Trends Over Time

$\begin{array}{ll}\text { Levels } & \\ \text { Baseline Time Trend } & 0.280 \\ & {[0.143]} \\ \text { (Japan)*Time Trend } & -0.498 \\ & {[0.185]^{* *}} \\ \text { (Indonesia)*Time Trend } & 0.923 \\ & {[0.294]^{* *}} \\ \text { (South Korea)*Time Trend } & 0.41 \\ & {[0.190]^{*}} \\ \text { (Thailand)*Time Trend } & 0.451 \\ & {[0.217]^{*}} \\ \text { (PRC)*Time Trend } & 2.091 \\ & {[0.185]^{* *}} \\ \text { (Czechoslovakia)*Time Trend } & -0.847 \\ & {[0.324]^{* *}} \\ \text { (Poland)*Time Trend } & -0.402 \\ & {[0.190]^{*}} \\ \text { (Romania)*Time Trend } & -0.382 \\ & {[0.190]^{*}} \\ \text { (New Zealand)*Time Trend } & -0.496 \\ & {[0.206]^{*}} \\ \text { Observations } & 806 \\ \text { R-squared } & 0.81 \\ \text { Standard errors in brackets } & \\ \text { *significant at 5\%; } & \\ & \end{array}$

Note: Only economies with statistically significant time trends reported 
Table 3. Top Twenty Antidumping Targets and Intensity Measures, 1995-2002

\begin{tabular}{clccccc}
\multicolumn{1}{c}{$\begin{array}{c}\text { Affected } \\
\text { Rank }\end{array}$} & $\begin{array}{c}\text { Economies } \\
\text { ED cases }\end{array}$ & $\begin{array}{c}\text { AD Share } \\
(95)\end{array}$ & $\begin{array}{c}\text { ADshare/ } \\
\text { Exportshare }\end{array}$ & $\begin{array}{c}\text { Affirmative } \\
\text { Ratio (\%) }\end{array}$ & $\begin{array}{c}\text { Product of tho intensity } \\
\text { measures }\end{array}$ \\
1 & China, P.R. & 308 & 14.3 & 4 & 69 & 2.76 \\
2 & South Korea & 160 & 7.4 & 4.8 & 52 & 2.50 \\
3 & United States & 115 & 5.3 & 0.4 & 58 & 0.23 \\
4 & China, Taipei & 109 & 5 & 4 & 63 & 2.52 \\
5 & Indonesia & 91 & 4.2 & 4.7 & 43 & 2.02 \\
6 & Japan & 88 & 4.1 & 0.6 & 73 & 0.44 \\
7 & India & 82 & 3.8 & 5.9 & 54 & 3.19 \\
8 & Thailand & 81 & 3.8 & 3.4 & 59 & 2.01 \\
9 & Russia & 77 & 3.6 & 2.1 & 71 & 1.49 \\
10 & Germany & 70 & 3.2 & 0.3 & 46 & 0.14 \\
11 & Brazil & 68 & 3.1 & 3.5 & 75 & 2.63 \\
12 & South Africa & 46 & 2.1 & 4.3 & 52 & 2.24 \\
13 & Ukraine & 46 & 2.1 & 7.1 & 83 & 5.89 \\
14 & Malaysia & 40 & 1.9 & 1.3 & 59 & 0.77 \\
15 & United Kingdom & 40 & 1.9 & 0.4 & 58 & 0.23 \\
16 & Italy & 39 & 1.8 & 0.5 & 48 & 0.24 \\
17 & Spain & 37 & 1.7 & 1 & 59 & 0.59 \\
18 & France & 32 & 1.5 & 0.3 & 54 & 0.16 \\
19 & Singapore & 32 & 1.5 & 1.3 & 72 & 0.94 \\
20 & Turkey & 30 & 1.4 & 2.8 & 41 & 1.15
\end{tabular}

Note: Chinese and Indian exports share are 95-02 average, while others using 2002 share. The reason is that other economies do not exhibit significant changes in share of world trade. 
Table 4. Chinese Exports Affected by AD by Two-digit ISIC Classification

\section{Industries}

35 - Manufacture of Chemicals and Chemical, Petroleum, Coal, Rubber and Plastic Products

38 - Manufacture of Fabricated Metal Products, Machinery and Equipment

32 - Textile, Wearing Apparel and Leather Industries

37 - Basic Metal Industries

36 - Manufacture of Non-Metallic Mineral Products, except Products of Petroleum and Coal

39 - Other Manufacturing Industries

31 - Manufacture of Food, Beverages and Tobacco

34 - Manufacture of Paper and Paper Products, Printing and Publishing
Number of

AD cases

158

105

62

55

31

21

17

8

6

4

4

3 
Table 5. Chinese Exports Affected by AD by Four-digit ISIC Classification

No. AD

Rank Sector Description

ISIC4

cases

1 Manufacture of basic industrial chemicals except fertilizers

$3511 \quad 80$

2 Iron and steel basic industries

$3710 \quad 46$

3 Manufacture of other chemical products

3522

23

4 Manufacture of footwear, except vulcanized or moulded rubber or plastic footwear

$3240 \quad 19$

5 Manufacturing industries not elsewhere classified

3909

19

6 Manufacture of fabricated metal products except machinery and equipment not elsewhere classified

3819

18

7 Manufacture of chemical products not elsewhere classified

3529

8 Manufacture of textiles not elsewhere classified

3219

15

9 Manufacture of cutlery, hand tools and general hardware

3811

15

10 Canning and preserving of fruits and vegetables

3113

14

11 Manufacture of glass and glass products

3620

14

12 Manufacture of motorcycles and bicycles

3844

14

3220

10

14 Manufacture of synthetic resins, plastic materials and man-made fibres except glass

$3513 \quad 10$

15 Manufacture of non-metallic mineral products not elsewhere classified

3699

9

16 Non-ferrous metal basic industries

3720

9

3512

8

Manufacture of plastic products not elsewhere classified

3560

Manufacture of radio, television and communication equipment and apparatus

3832

Manufacture of electrical appliances and housewares

3833

Manufacture of electrical apparatus and supplies not elsewhere classified

All others 
Table 6. The Initiating Economies Targeting Chinese Exports

\begin{tabular}{lccc} 
Initiator & $\begin{array}{c}\text { Number } \\
\text { of Filings }\end{array}$ & $\begin{array}{c}\text { Exports from China } \\
\text { (million US. dollars) }\end{array}$ & $\begin{array}{c}\text { Intensity } \\
\text { Relative to US }\end{array}$ \\
\hline US & 87 & 54359 & 1.0 \\
EU & 66 & 40953 & 1.0 \\
India & 55 & 1896 & 18.1 \\
Australia & 48 & 3570 & 8.4 \\
Argentina & 43 & 574 & 46.8 \\
Mexico & 43 & 1790 & 15.0 \\
Canada & 21 & 3346 & 3.9 \\
Brazil & 20 & 1351 & 9.2 \\
South Africa & 16 & 1049 & 9.5 \\
Korea & 14 & 12521 & 0.7 \\
Peru & 12 & 177 & 42.4 \\
Turkey & 12 & 674 & 11.1 \\
Venezuela & 10 & 443 & 14.1 \\
New Zealand & 8 & 435 & 11.5 \\
All Others & 19 & &
\end{tabular}

Source of exports data: Direction of Trade Statistics Yearbook 2002.

Table 7. Economies that Initiated WTO Disputes on Antidumping Measures

\begin{tabular}{lc}
\hline Initiating Economy & $\begin{array}{c}\text { No. of } \\
\text { disputes }\end{array}$ \\
\hline European Community & 9 \\
Mexico & 9 \\
Brazil & 7 \\
India & 5 \\
Canada & 5 \\
United States & 4 \\
South Korea & 4 \\
Japan & 3 \\
All Others & 14 \\
of which China & 0 \\
\hline \hline
\end{tabular}

Source: WTO official website, http://www.wto.org/english/tratop_e/dispu_e/dispu_subjects_index_e.htm\#bkmk4 
Table 8. Poisson regression: Effects of FDI on AD filings

Number of obs $=17$

LR chi2(3) $=175.27$

Prob $>$ chi $2=0.0000$

Pseudo R2 $=0.5758$

Log likelihood $=\quad-64.568$

\begin{tabular}{|l|l|l|l|l|l|l|}
\hline & Estimate & Std.Err. & t-stat & p-value & \multicolumn{2}{|c|}{ 99\% Conf. Interval] } \\
\hline FDI & 0.7701904 & .1495 & 5.15 & 0.000 & .3848 & 1.155 \\
\hline Exports & 0.1133838 & .2241 & 0.51 & 0.613 & -.4639 & .6907 \\
\hline Ex. Rate & -.1553 & .0863375 & -1.80 & 0.072 & -.3776 & .0671 \\
\hline Constant & -1.050289 & 2.075 & -0.51 & 0.613 & -6.396 & 4.295 \\
\hline
\end{tabular}


Figure 1. Filing Trend Over Time

Rurning maan smoother, bandwidth $=.8$

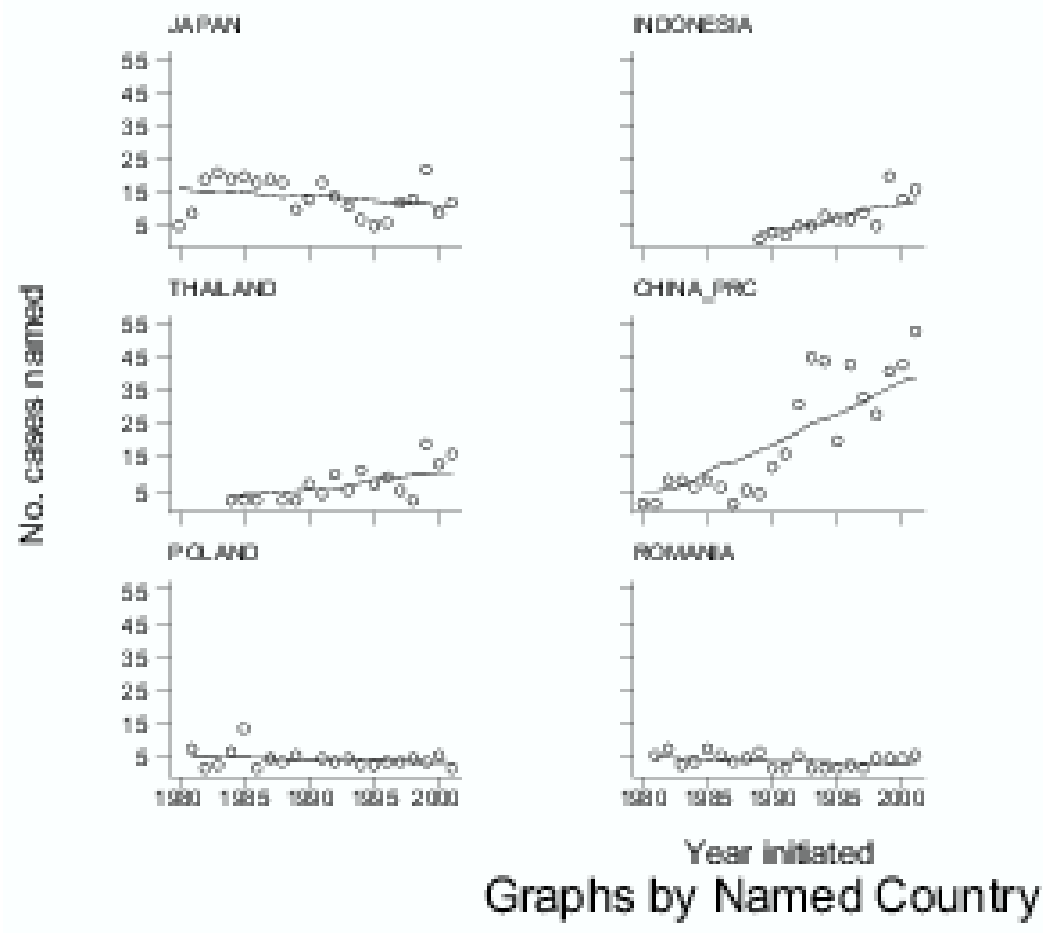

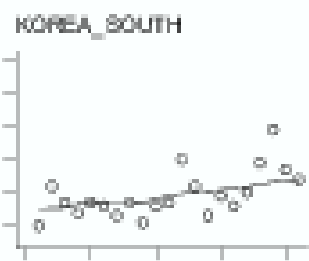

CAEHOELWMOA
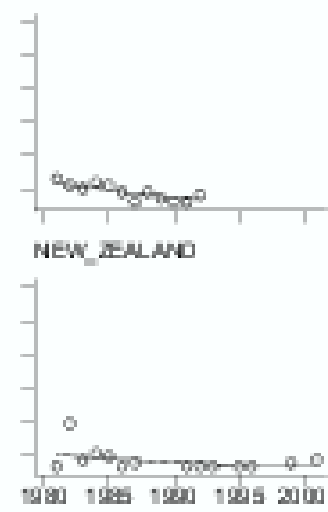
Figure 2. The Antidumping Duties Imposed by the US on Chinese Exports

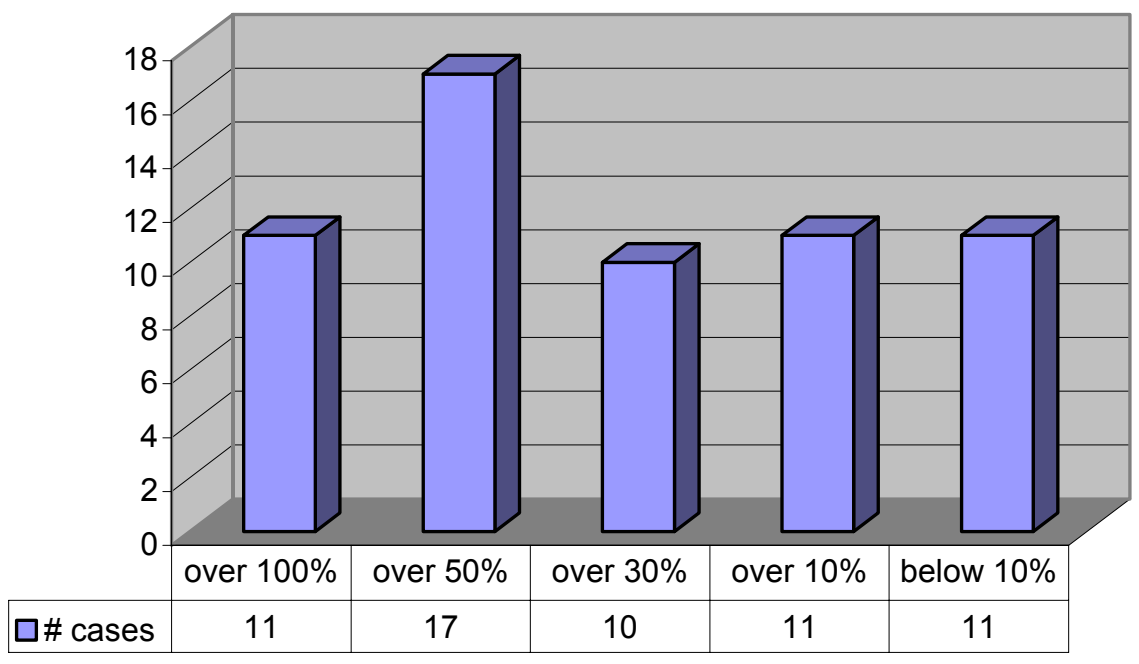


Figure 3. The AD filed against and the FDI in China

\section{Log FDI and Log \# of AD Cases}

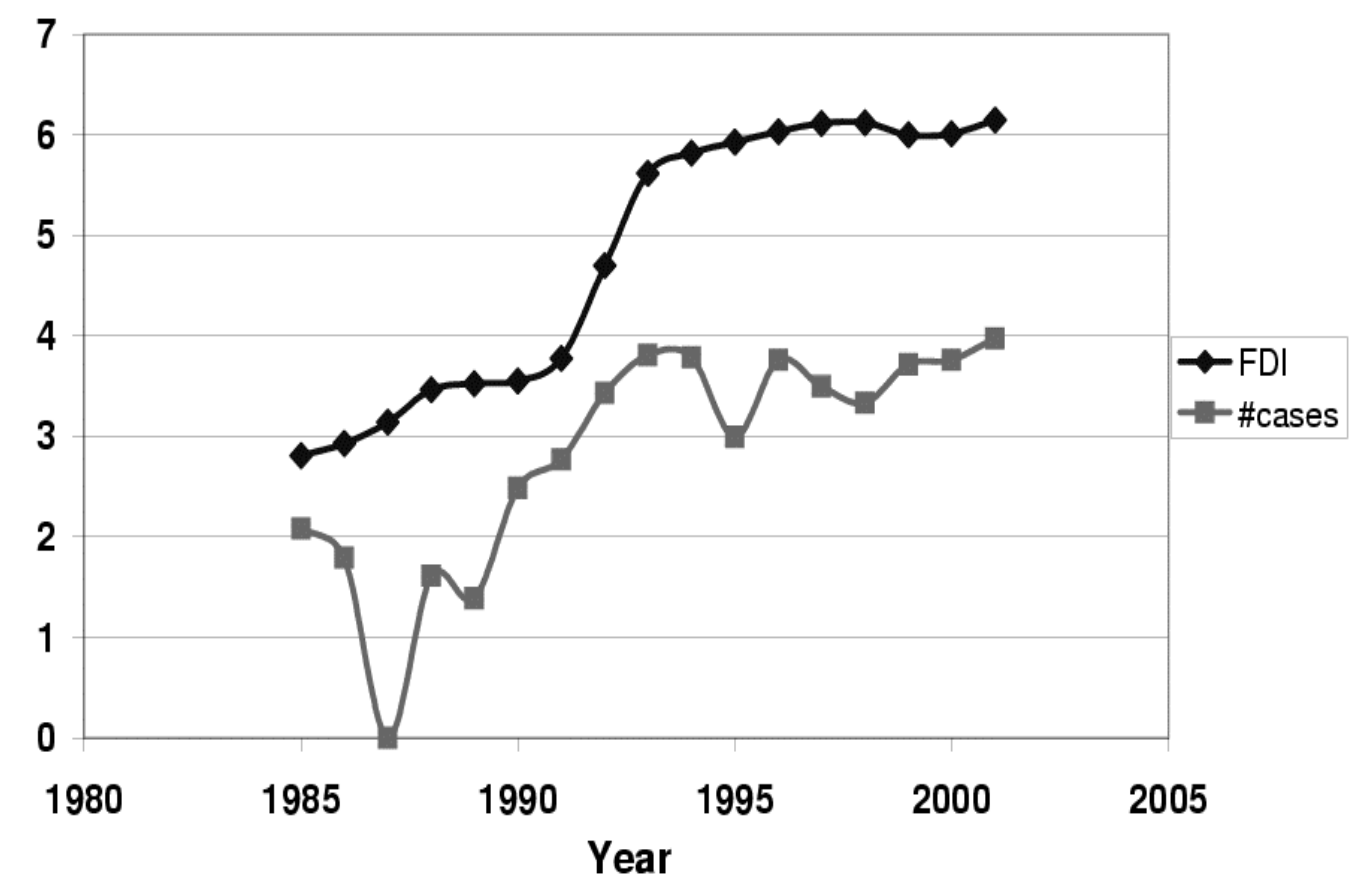


Figure 4. Number of AD Cases filed by China

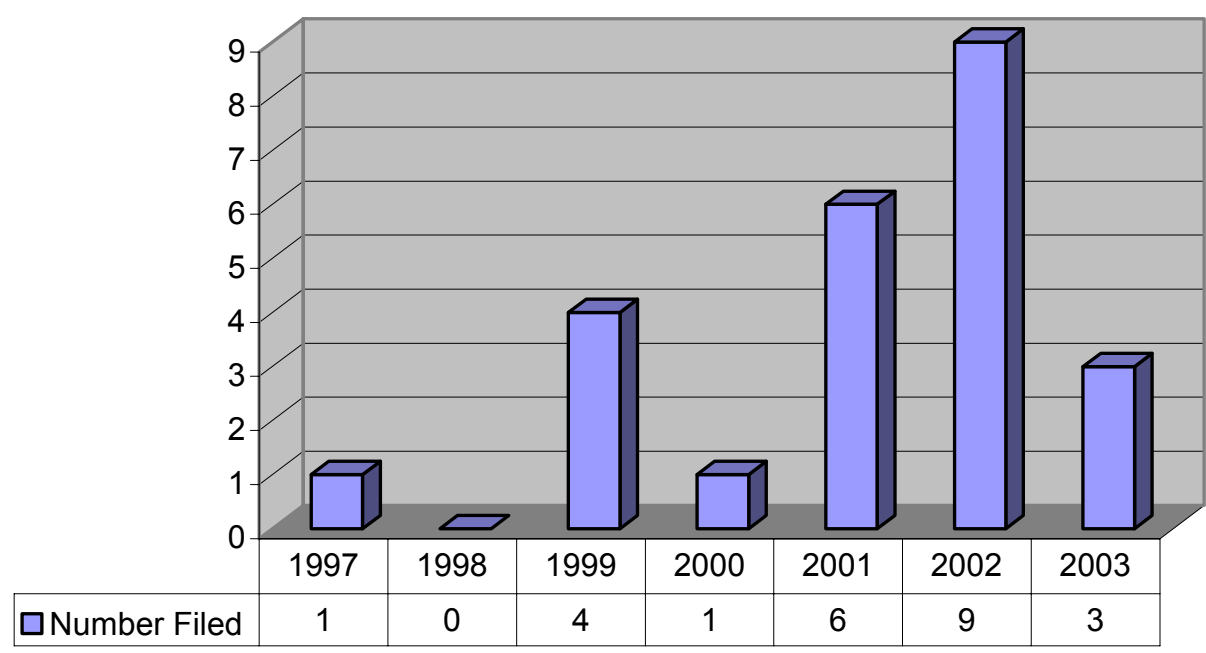




\section{East-West Center Working Papers: Economics Series}

No. 1 Inter-Organizational Knowledge Outsourcing: What Permits Small Taiwanese Firms to Compete in the Computer Industry?, by Dieter Ernst, May 2000.

No. 2 Catching-Up and Post-Crisis Industrial Upgrading: Searching for New Sources of Growth in Korea's Electronics Industry, by Dieter Ernst, May 2000.

No. 3 Carriers of Cross-Border Knowledge Diffusion: Information Technology and Global Production Networks, by Dieter Ernst, June 2000.

No. 4 IT and the e-Economy: The Ballast for India-U.S. Relations, by Sanjaya Baru, September 2000.

No. 5 Placing the Networks on the Web: Challenges and Opportunities for Managing in Developing Asia, by Dieter Ernst, September 2000.

No. 6 The Impact of Imported and Domestic Technologies on Productivity: Evidence from Indian Manufacturing Firms, by Rana Hasan, September 2000.

No. 7 The Economics of Electronics Industry: Competitive Dynamics and Industrial Organization, by Dieter Ernst, October 2000.

No. 8 Information Technology in the Learning Economy: Challenges for Developing Countries, by Dieter Ernst and Bengt- Åke Lundvall, October 2000.

No. 9 Global Production Networks and the Changing Geography of Innovation Systems: Implications for Developing Countries, by Dieter Ernst, November 2000.

No.10 Moving Beyond the Commodity Trap? Trade Adjustment and Industrial Upgrading in East Asia's Electronics Industry, by Dieter Ernst, January 2001.

No. 11 Trade Relations of Korea and Japan: Moving from Conflict to Cooperation?, by William E. James, January 2001.

No. 12 Knowledge Management: A New Perspective for Development Strategy, by Linsu Kim, January 2001.

No. 13 Understanding Technological Change, by Richard G. Lipsey, February 2001.

No. 14 Inter-Firm Linkages and Development of Capabilities in the Indian Telecom Software Sector, by Rakesh Basant, Pankaj Chandra, and Lynn Mytelka, February 2001.

No. 15 Global Production Networks and Local Capabilities: New Opportunities and Challenges for Taiwan, by Tain-Jy Chen and Shin-Horng Chen, February 2001.

No. 16 Industrial Districts, ICT and Global Production Networks: The Italian Experience, by Paolo Guerrieri, February 2001.

No. 17 E-Commerce and the Semiconductor Industry Value Chain: Implications for Vertical Specialization and Integrated Semiconductor Manufacturers, by David C. Mowery and Jeffrey T. Macher, May 2001. 


\section{East-West Center Working Papers: Economics Series}

No. 18 Electronics Contract Manufacturing: Transnational Production Networks, the Internet, and Knowledge Diffusion in Low-Cost Locations in Asia and Eastern Europe, by Boy Luethje, May 2001.

No. 19 Global Production Networks, Knowledge Diffusion, and Local Capability Formation. A Conceptual Framework, by Dieter Ernst and Linsu Kim, May 2001.

No. 20 The "Hidden" Side of the "flying-Geese" Model of Catch-Up Growth: Japan's Dirigiste Institutional Setup and a Deepening Financial Morass, by Terutomo Ozawa, May 2001.

No. 21 Does Investing in Technology Affect Exports? Evidence from Indian Firms, by Rana Hasan and Mayank Raturi, May 2001.

No. 22 International Economic Integration and Labor Markets in Developing Countries: The Case of Indonesia, by Asep Suryahadi, May 2001.

No. 23 Globalisation, Economic Crisis and Labour Market Policy: Lessons from East Asia, by Chris Manning, May 2001.

No. 24 Trade Policy Reform and Labor Market Dynamics: Issues and an Agenda for Future Research, by Steven J. Matusz, May 2001.

No. 25 Global Production Networks and Industrial Upgrading - A Knowledge-Centered Approach, by Dieter Ernst, May 2001.

No. 26 Globalization and Wage Inequality in Indonesia: A CGE Analysis, by Asep Suryahadi, May 2001.

No. 27 Multinational Corporations and Endogenous Growth: an Eclectic-Paradigmatic Analysis, by Terutomo Ozawa and Sergio Castello, May 2001.

No. 28 The Evolution of a "Digital Economy": Research Issues and Policy Challenges, by Dieter Ernst, July 2001.

No. 29 Trade Liberalization, Labor Markets and Imperfect Competition, by Devashish Mitra, July 2001.

No. 30 The New Mobility of Knowledge: Digital Information Systems and Global Flagship Networks, by Dieter Ernst, July 2001. (See W.P.\# 56 for revised version)

No. 31 Governing Electronic Commerce in a Global Environment, by D. Linda Garcia, August 2001.

No. 32 The Impact of Trade and Labor Market Regulations on Employment and Wages: Evidence from Developing Countries, by Rana Hasan, August 2001.

No. 33 The Internet's Effects on Global Production Networks: Challenges and Opportunities for Managing in Developing Asia, by Dieter Ernst, August 2001.

No. 34 Private Profit or Public Purpose? Corporate Governance Convergence and the Asian State, by James Shinn, September 2001. 


\section{East-West Center Working Papers: Economics Series}

No. 35 Implications, Challenges and Prospects for Taiwan in the Knowledge-based Economy, by Tain-Jy Chen, Shin-Horng Chen, and Meng-chun Liu, September 2001.

No. 36 From Digital Divides to Industrial Upgrading. Information and Communication Technology and Asian Economic Development, by Dieter Ernst, October 2001.

No. 37 Transnational Communities and the Evolution of Global Production Networks: The Cases of Taiwan, China and India, by AnnaLee Saxenian, December 2001.

No. 38 The Impact of Minimum Wage Policy on Wages and Employment in Developing Countries: The Case of Indonesia, by Asep Suryahadi, Wenefrida Widyanti, Daniel Perwira, and Sudarno Sumarto, December 2001.

No. 39 Intellectual Property Rights in China: The Changing Political Economy of ChineseAmerican Interests, by Sumner La Croix and Denise Eby Konan, January 2002.

No. 40 Knowledge Flows and Industrial Clusters: An Analytical Review of Literature, by Rakash Basant, February 2002.

No. 41 Globalization and Workers in Developing Countries, by Martín Rama, February 2002.

No. 42 National Sovereign Economy, Global Market Economy, and Transnational Corporate Economy, by Dieter Ernst and Terutomo Ozawa, March 2002.

No. 43 Do Global Production Networks and Digital Information Systems make Knowledge Spatially Fluid?, by Dieter Ernst, Jan Fagerberg, and Jarle Hildrum, March 2002.

No. 44 Global Production Networks in East Asia's Electronics Industry and Upgrading Perspectives in Malaysia, by Dieter Ernst, March 2002. [Revised October 2002]

No. 45 Production Networks of Japanese and American Automobile Industry: Contrasting Evolution and Convergence, by Takashi Hayashi, May 2002.

No. 46 Global Production Networks and Information Technology: The Case of Taiwan, by SingHorng Chen, May 2002.

No. 47 eBusiness and the Semiconductor Industry Value Chain: Implications for Vertical Specialization and Integrated Semiconductor Manufacturers, by Jeffrey T. Macher, David C. Mowery, and Timothy S. Simcoe, May 2002.

No. 48 Digital Information Systems and Global Flagship Networks: How Mobile is Knowledge in the Global Network Economy, by Dieter Ernst, May 2002.

No. 49 Land Tenure: An Introduction, by Sumner La Croix, June 2002.

No. 50 Trade and Labour Market Linkages in India: Evidence and Issues, by Rayaprolu Nagaraj, August 2002.

No. 51 Multinational Firms and the Evolution of the Indian Software Industry, by Suma S. Athreye, January 2003.

No. 52 R\&D Services and Global Production Networks: A Taiwanese Perspective, by ShinHorng Chen, Meng-Chun Liu, and Hui-Tzu Shih, March 2003. 


\section{East-West Center Working Papers: Economics Series}

No. 53 U.S.-India Technology Cooperation and Capability Building: The Role of Inter-Firm Alliances in Knowledge Based Industries, by Rakesh Basant, March 2003.

No. 54 Globalization and Industrial Labor Markets in South Asia: Some Aspects of Adjustment in a Less Integrated Region, by Krishnarajapet V. Ramaswamy, April 2003.

No. 55 Key Players in the Asia Pacific Oil Market, by Jeffrey Brown and Kang Wu, May 2003.

No. 56 The New Mobility of Knowledge: Digital Information Systems and Global Flagship Networks, by Dieter Ernst, June 2003.

No. 57 How Sustainable are Benefits from Global Production Networks? Malaysia's Upgrading Prospects in the Electronics Industry, by Dieter Ernst, June 2003.

No. 58 Pathways to Innovation in the Global Network Economy: Asian Upgrading Strategies in the Electronics Industry, by Dieter Ernst, June 2003.

No. 59 Trade Reforms, Labor Regulations and Labor-Demand Elasticities: Empirical Evidence from India, by Rana Hasan, Devashish Mitra, and K.V. Ramaswamy, June 2003.

No. 60 Poverty and Economic Freedom: Evidence from Cross-Country Data, by Rana Hasan, M.G. Quibria, and Yangseon Kim, September 2003.

No. 61 Trade and Workers: Evidence from the Philippines, by Rana Hasan and Lan Chen, September 2003.

No. 62 Pathways to Innovation in Asia's Leading Electronics Exporting Countries - Drivers and Policy Implications, by Dieter Ernst, October 2003.

No. 63. Global Production Networks, Innovation and Work - Why Chip and System Design are Moving to Asia, by Dieter Ernst and Boy Lüthje, October 2003.

No. 64 Internationalisation of Innovation: Why is chip design moving to Asia?, by Dieter Ernst, revised March 2004.

No. 65 Modularity and the Organization of International Production, by Ari Van Assche, November 2003.

No. 66 Late Innovation Strategies in Asian Electronics Industries: A Conceptual Framework and Illustrative Evidence, by Dieter Ernst, March 2004.

No. 67 Estimation of the J-Curve in China, by Jaleel Admad and Jing Yang, March 2004.

No. 68 Searching for a New Role in East Asian Regionalization - Japanese Production Networks in the Electronics Industry, by Dieter Ernst, March 2004.

No. 69 The Reasons for and the Impact of Antidumping Protection: The Case of People's Republic of China, by Tianshu Chu and Thomas J. Prusa, April 2004. 